\title{
A Generation of the Canadian Journal of Science, Mathematics and Technology Education
}

\author{
Douglas McDougall $(\mathbb{D}$
}

Accepted: 11 December 2020 / Published online: 17 January 2021

(C) Ontario Institute for Studies in Education (OISE) 2021

Quite often, we think of a generation as being about 20 years long. The Canadian Journal of Science, Mathematics and Technology Education (CJSMTE) is 20 years old. In this issue, we continue our celebration that began in Volume 20 Issue 3 with the Chernoff (2020) and Lajoie (2020). In Volume 20 Issue 4, we present papers from our authors who accepted the invitation to think about the past, present and/ or future of the journal. These authors are former editors-in-chief, editors, Editorial Board members and frequent authors. They are long-term supporters of the journal and I am thankful for the time they took to provide us with their history and insight as we celebrate the 20 years of CJSTME.

We begin the issue with articles from the founding editors. Derek Hodson (2021) writes about the key issues that need to be addressed in building a curriculum for sociopolitical activism. He describes a fourstage model to build students' capacity for sociopolitical action on socioscientific issues (SSI). He recognizes that there are many reasons why this kind of curriculum will be "extraordinarily complex and difficult" but well worth the time and effort. Gila Hanna (2020a, b) provides a commentary, in both English and French, about the 20 years of the journal. She describes the key factors in the ongoing success of the journal including a stellar editorial board, the appointment of new editors and bringing together anglophone and francophone researchers and educators. She feels the journal can "confidently look forward" to a productive life. Jacques Desautels (2021) provides an example of science and politics in L'enseignement des sciences et le politique: un exemple. He explores the revised program of natural sciences at the college level in Quebec and the stakeholders in the design of the program. This French article looks at the political issues of curriculum design, and how Desautels arrives back where he was 20 years ago.

Following the leadership of these three exceptional authors and professors, John Wallace became the Editor-in-chief in 2007 until 2018. Joining him on the editorial team were Rina Zazkis and Nathalie Sinclair. Zazkis' (2021) article focused on mathematical knowledge in teaching based on a special issue called "Personal Mathematical Knowledge in the Work of Teaching" (CJSMTE 13(2), 2013). She integrates the ideas presented by the authors of the 2013 Special Issue with examples from her own teaching. Sinclair (2021) writes about whether this is the appropriate time to spatialise, transdiscipline and deconstruct CJSMTE. She examines CJSTME's articles from the past 20 years to consider how CJSMTE relates to more global issues of educational research and how the different paradigms of research have been represented over time, particularly for mathematics education.

D. McDougall $(\bowtie)$

Ontario Institute for Studies in Education, University of Toronto, 252 Bloor Street West, Toronto, Ontario M5S 1V6, Canada e-mail: doug.mcdougall@utoronto.ca 
Jérôme Proulx (2021) writes about various orientations in mathematics didactics. He writes about common dimensions and distinctions to clarify the research work that needs to be done while illustrating that the field is dynamic and in constant renewal. Ann Kajander (2021) looks at the status of mathematics research and how we can move forward in understanding mathematics teaching and learning. She looks back at previous research and theorizes about the role of mathematics education research moving forward.

Wolff-Michael Roth (2020) looks back and forward through a personal lens to provide an historical perspective. He uses his own classroom experiences to transform classrooms and outlines some future research ideas that could be investigated by younger generations of SMTE researchers. This line of work has been published almost exclusively in CJSMTE. Karen Goodnough (2021) reflects on professional learning through the lens of a science teacher educator. She describes how the journal has benefitted her professional learning through her various roles in the journal: Editorial Board member, author, reviewer and consumer. She provides invaluable advice to science teacher educators that will assist them to meet their professional learning goals.

Glen Aikenhead (2021) provides a view of school mathematics and science through the use of two storylines. The first story looks back at the articles about enhancing and enriching school science with Indigenous ways of living in Mother Earth. A second storyline is a future perspective about enhancing school mathematics with Indigenous mathematizing, complete with a recent research study that provides details about this new trajectory. Erminia Pedretti and Ana Maria Navas Iannini (2021) look at the changing goals and roles for fourth-generation science museums. They see science museums as reshaping their identity to promote active citizenship, social responsibility, engagement with complex science and technology issues, and agency. They suggest that these institutions are evolving, and revisiting and repurposing themselves to become more than they have been historically.

Gary Pluim, Joanne Nazir and John Wallace (2021) explore Basil Bernstein's Classification and Framing of Educational Knowledge through the lens of curriculum integration. The authors specifically investigate who benefits from curriculum integration, looking at six categories. They propose that a Worldly Perspective is an approach that would move us forward in STEM fields. A frequent author to the journal, Larry Bencze (2021), writes about activist science, mathematics and technology education by re-visioning ideological assemblages. He reviews the characteristics and extensive harms linked to science, mathematics, technology and engineering and then describes a curriculum and pedagogical framework that can encourage and enable students to imagine and actively promote assemblage of diverse entities into alliances that they consider appropriate.

David Blades (2021) was the founding editor of Newsround, previously a feature of CJSMTE designed to "serve as a way of reporting on current events in SMTE across the country and on the people behind these events" (Blades, 2001, p. 123). Larry Bencze, another author in this issue, was the second editor of Newsround until 2007. In this article, Blades demonstrates the importance of fostering a sense of community that can be achieved by publishing a Newsround / Nouvelles brèves. The editors of CJSMTE have taken his proposal as an important discussion point for Volume 21.

Lastly, McDougall and Ferreyro Mazieres (2021) look back at the past 20 years of CJSMTE's articles and viewpoints to identify some patterns. The findings suggest that there was an increase in mathematics education articles, balancing the proportion of science articles to mathematics articles, as well as an increased focus on technology education articles and STEM articles over the past five years. The authors propose that the journal leadership team should plan to add Africa, particularly from francophone authors, to the call to increase CJSMTE's international voices over the next few years.

The CJSMTE was created in 2001 to build a community of educators and researchers in science, mathematics and technology education, locally, nationally and internationally. The editors-in-chief, editors and editorial assistants, along with a supportive Editorial Board, reviewers and authors have assisted the journal to expand its reach globally. The journal is a generation old. Thank you to each of you in the role you played in helping build this community. This special issue has provided us with an opportunity to celebrate 20 fabulous years and to launch us into the third decade of the CJSMTE. On y va! 


\section{Compliance with Ethical Standards}

Conflict of Interest The author declares that there is no conflict of interest.

\section{References}

Aikenhead, G. (2021). School science and mathematics storylines. Canadian Journal for Science, Mathematics and Technology, 20(4). https://doi.org/10.1007/s42330-020-00115-5.

Bencze, J.L. (2021). Re-visioning ideological assemblages through de-punctualizing and activist science, mathematics \& technology education. Canadian Journal for Science, Mathematics and Technology, 20(4). https://doi.org/10.1007 /s42330-020-00133-3.

Blades, D. (2001). Newsround. Canadian Journal of Science, Mathematics and Technology Education, 1(1), 124-134.

Blades, D. (2021). Newsround: A repetition. Canadian Journal for Science, Mathematics and Technology, 20(4). https://doi. org/10.1007/s42330-020-00122-6.

Chernoff, E.J. (2020). On the occasion of an anniversary, eh: Confessions of a Canadian math ed editor. Canadian Journal for Science, Mathematics and Technology, 20(3), 397-411.

Desautels, J. (2021). L'enseignement des sciences et le politique: un exemple. Canadian Journal for Science, Mathematics and Technology, 20(4). https://doi.org/10.1007/s42330-020-00131-5.

Goodnough, K. (2021). Professional learning and the Canadian Journal of Science, Mathematics and Technology Education: Reflections of a science teacher educator. Canadian Journal for Science, Mathematics and Technology, 20(4). https://doi. org/10.1007/s42330-020-00119-1.

Hanna, G. (2020a). In celebration of the 20th Anniversary of the Canadian Journal of Science, Mathematics and Technology Education (CJSMTE). Canadian Journal for Science, Mathematics and Technology, 20(4). https://doi.org/10.1007 /s42330-020-00106-6.

Hanna, G. (2020b). À l'occasion du $20^{\mathrm{e}}$ anniversaire de la Revue canadienne de l'enseignement des sciences, des mathématiques et de la technologie (CJSMTE). Canadian Journal for Science, Mathematics and Technology, 20(4). https://doi.org/10.1007/s42330-020-00117-3.

Hodson, D. (2021). Going beyond STS education: Building a curriculum for sociopolitical activism. Canadian Journal for Science, Mathematics and Technology, 20(4). https://doi.org/10.1007/s42330-020-00114-6.

Kajander, A. (2021). The mandate of scholarly mathematics education research: Moving ourselves forward. Canadian Journal for Science, Mathematics and Technology, 20(4). https://doi.org/10.1007/s42330-020-00121-7.

Lajoie, C. (2020). La Revue canadienne de l'enseignement des sciences, des mathématiques et des technologies: une vitrine de choix pour la diffusion en français de réflexions et recherches en didactique des mathématiques. Canadian Journal for Science, Mathematics and Technology, 20(3), 412-422.

McDougall, D. \& Ferreyro Mazieres, S. (2021). CJSMTE: 20 years strong. Canadian Journal for Science, Mathematics and Technology, 20(4). https://doi.org/10.1007/s42330-020-00120-8.

Pedretti, E. (2021). A Towards fourth generation science museums: Changing goals, changing roles. Canadian Journal for Science, Mathematics and Technology, 20(4). https://doi.org/10.1007/s42330-020-00128-0.

Pluim, G., Nazir, J., \& Wallace, J. (2021). Curriculum integration and the semicentennial of Basil Bernstein's Classification and Framing of Educational Knowledge. Canadian Journal for Science, Mathematics and Technology, 20(4). https://doi. org/10.1007/s42330-021-00135-9.

Proulx, J. (2021). Des variétés de didactiques des mathématiques: réaffirmer le commun et tracer des distinctions. Canadian Journal for Science, Mathematics and Technology, 20(4). https://doi.org/10.1007/s42330-020-00129-z.

Roth, W-R. (2020). Looking back and looking forward: A historical perspective on science, mathematics, and technology education in Canada through a personal lens. Canadian Journal for Science, Mathematics and Technology, 20(4). https://doi.org/10.1007/s42330-020-00113-7.

Sinclair, N. (2021). Time to spatialise, transdiscipline and deconstruct CJSMTE? Canadian Journal for Science, Mathematics and Technology, 20(4). https://doi.org/10.1007/s42330-020-00127-1.

Zazkis, R. (2021). Personal, nonlocal, tacit: On mathematical knowledge in teaching. Canadian Journal for Science, Mathematics and Technology, 20(4). https://doi.org/10.1007/s42330-020-00118-2.

Publisher's Note Springer Nature remains neutral with regard to jurisdictional claims in published maps and institutional affiliations. 